\title{
LUT
}

University

Effects of energy retrofits on Indoor Air Quality in multifamily buildings

\author{
Du L., Leivo V., Prasauskas T., Täubel M., Martuzevicius D., Haverinen- \\ Shaughnessy U.
}

This is a Post-print version of a publication

published by John Wiley \& Sons

in Indoor Air

DOI: $10.1111 /$ ina. 12555

Copyright of the original publication: @ 2019 John Wiley \& Sons

Please cite the publication as follows:

Du, L., Leivo, V., Prasauskas, T., Täubel, M., Martuzevicius, D., Haverinen-Shaughnessy, U.

(2019). Effects of energy retrofits on Indoor Air Quality in multifamily buildings. Indoor Air, vol. 29, issue 4. pp. 686-697. DOI: 10.1111/ina.12555

This is a parallel published version of an original publication.

This version can differ from the original published article. 


\section{Effects of Energy Retrofits on Indoor Air Quality in Multifamily Buildings}

2 Liuliu Du ${ }^{1 \dagger}$, Virpi Leivo ${ }^{2}$, Tadas Prasauskas ${ }^{3}$, Martin Täubel ${ }^{1}$, Dainius Martuzevicius ${ }^{3}$, and

3 Ulla Haverinen-Shaughnessy ${ }^{1,2}$ *

$4 \quad{ }^{1}$ Department of Health Security, National Institute for Health and Welfare, P.O. Box 95, 70701

$5 \quad$ Kuopio, Finland

62 Department of Civil Engineering, Tampere University, P.O. Box 600

733101 Tampere, Finland

$8{ }^{3}$ Department of Environmental Technology, Kaunas University of Technology, K. Donelaičio

$9 \quad$ St. 73, 44249 Kaunas, Lithuania

10

$11 \dagger$ Current affiliation: Department of Sustainability Science, Lappeenranta University of

12 Technology, Lappeenranta, Finland

13 † Corresponding author:

14 Ulla Haverinen-Shaughnessy

15 National Institute for Health and Welfare, P.O. Box 95, 70701 Kuopio, Finland

16 Tel: +358 50917 2374; Email: ulla.haverinen@thl.fi 


\section{Abstract:}

2 We assessed 45 multifamily buildings (240 apartments) from Finland and 20 from (96 3 apartments) Lithuania, out of which 37 buildings in Finland and 15 buildings in Lithuania 4 underwent energy retrofits. Building characteristics, retrofit activities, and energy consumption 5 data were collected, and indoor air quality (IAQ) parameters, including carbon monoxide (CO), 6 nitrogen dioxide $\left(\mathrm{NO}_{2}\right)$, formaldehyde $\left(\mathrm{CH}_{2} \mathrm{O}\right)$, selected volatile organic compounds (benzene, 7 toluene, ethyl benzene and xylenes (BTEX)), radon, and microbial content in settled dust were 8 measured before and after the retrofits. After the retrofits, heating energy consumption decreased by an average of $24 \%$ and $49 \%$ in Finnish and Lithuanian buildings, respectively. After the retrofits of Finnish buildings, there was a significant increase in BTEX concentrations (estimated mean increase $2.5 \mu \mathrm{g} \mathrm{m}^{-3}$ ), whereas significant reductions were seen in fungal (0.6$\log$ reduction in cells $/ \mathrm{m}^{2} / \mathrm{d}$ ) and bacterial (0.6-log reduction in gram-positive and 0.9-log reduction in gram-negative bacterial cells $/ \mathrm{m}^{2} / \mathrm{d}$ ) concentrations. In Lithuanian buildings, radon concentrations were significantly increased (estimated mean increase $13.8 \mathrm{~Bq} \mathrm{~m}^{-3}$ ) after the retrofits. Mechanical ventilation was associated with significantly lower $\mathrm{CH}_{2} \mathrm{O}$ concentrations in Finnish buildings. The results and recommendations presented in this paper can inform building retrofit studies and other programs and policies aimed to improve indoor environment and health.

Keywords: bacteria; chemical exposure; fungi, microbial exposure; radon, residential building

Practical implications: As compared to the situation before energy retrofits, largest differences after the retrofits were seen in microbial concentrations in settled dust. Mechanical ventilation was related to lower concentrations of certain gaseous pollutants, whereas naturally ventilated buildings were at risk of reduced IAQ, potentially due to inadequate ventilation 
1 (pertaining to removal/dilution of indoor pollutants). There was a relatively small but

2 statistically significant increase in radon concentrations in Lithuanian buildings. It is

3 recommended for building owners to check at least ventilation rates and radon levels after

4 major retrofits to ensure compliance with national standards, and EU/national authorities to

5 ensure that IAQ is taken into account in their policies and programs related to energy retrofits.

\section{Introduction}

7 In order to fulfill the recast 2010 Energy Performance of Buildings Directive (2010/31/EC),

8 new buildings and existing buildings subjected to major renovation have to meet minimum

9 energy performance targets adapted to the local climate ${ }^{1}$. Policies, for example, regulations

such as building codes are used to help achieve this goal ${ }^{2,3}$. However, these polices are mainly focused on new buildings ${ }^{4}$, and not necessarily applicable for existing buildings undergoing retrofits. As a whole, residential buildings represent about $23 \%$ of the total energy use ${ }^{5}$ and over $50 \%$ of the European population resides in multifamily buildings, which are commonly targeted for energy efficiency (EE) improvements ${ }^{6}$. However, building regulations related to $\mathrm{EE}$ (such as air tightness, ventilation) differ largely across the EU resulting in large differences in energy use in practice ${ }^{7}$.

Studies have demonstrated that energy retrofits can results in significant value of saved energy ${ }^{8-11}$ well as the co-benefits related to indoor thermal comfort, and user satisfaction ${ }^{12-14}$. The societal effects include meeting sustainability objectives with low carbon technologies as well as possible health effects ${ }^{15-18}$. However, there are many challenges that may jeopardize an overall objective for better EE, health and wellbeing. These challenges include control of thermal conditions ${ }^{19}$, indoor pollutants ${ }^{20,21}$, and noise related to mechanical systems ${ }^{22}$, as well as occupants' interaction with indoor environment and various socio-economic issues ${ }^{23}$. 
1 A limited number of studies worldwide have assessed the potential effects of improved EE on

2 IAQ. Such studies using quantitative, using objective measurements are mostly case studies

3 involving a few buildings and/or a single multifamily complex. For example, Norris et al. ${ }^{24}$

4 studied sixteen apartments in three buildings in California, USA before and shortly after energy

5 retrofits, where the intent was to provide continuous mechanical ventilation at 1.5 times the

6 rate specified in ASHRAE Standard 62.2, whereas energy consumption before and after

7 retrofits was not reported. The IAQ parameters measured included $\mathrm{CO}_{2}, \mathrm{CO}, \mathrm{PM} 2.5, \mathrm{NO}_{2}$,

8 acetaldehyde, $\mathrm{CH}_{2} \mathrm{O}$, and a suite of volatile organic compounds (VOCs). Radon or microbial

9 pollutants were not assessed. It was reported that overall IAQ improved after the retrofits.

10 Larger decreases in indoor pollutants were linked to larger increases in ventilation. Coombs et

11 al. ${ }^{25}$ assessed IAQ of 42 low-income green and non-green homes in one multi-family housing complex in Ohio, USA. Post-renovation data on green-renovated homes was collected during three home visits over one year period. Six pollutants were measured indoors: $\mathrm{PM}_{2.5}$, black carbon (BC), sulfur (S), ultrafine particles (UFP), TVOCs and $\mathrm{CH}_{2} \mathrm{O}$, of these, $\mathrm{BC}$ decreased and $\mathrm{CH}_{2} \mathrm{O}$ increased immediately post-renovation. It was concluded that occupants' activities affected IAQ more than the renovation status. Breysse et al. ${ }^{26}$ studied a 60 -unit apartment complex that underwent substantial green renovation in Minnesota, US. The assessment included building performance testing and measurements of radon and $\mathrm{CO}_{2}$, as well as overall energy use before and one year after renovation. Post-renovation testing indicated that the building envelope was tightened. New mechanical ventilation was installed (compared with no ventilation previously), with fresh air being supplied at $70 \%$ of the ASHRAE standard. Radon was 2 picocuries per liter of air (i.e. $<100 \mathrm{~Bq} / \mathrm{m}^{3}$ ) following mitigation, and the annual average indoor $\mathrm{CO}_{2}$ level was $982 \mathrm{ppm}$. Energy use was reduced by $45 \%$ over the one-year postrenovation period. 
1 This study was conducted as a part of INSULAtE-project in two countries in northeastern

2 Europe, namely Finland and Lithuania. The two countries have very distinct premises and

3 characteristics with respect to energy use, building stock, and ways of implementing national

4 policies within $\mathrm{EU}^{27}$. In terms of implementing EPBD over the past decades, Finnish

5 government has supported energy retrofits of residential buildings ${ }^{28}$ and frequently updated

6 regulations, such as National Building Code C3, "Thermal insulation in buildings" and new

7 degrees on statue of Finland ${ }^{29}$. Currently, the calculation of energy class for energy certificate

8 takes into account of the total energy consumption multiplied with energy source coefficient ${ }^{30}$,

9 on a scale ranging from A (high) to $\mathrm{G}$ (poor) ${ }^{29,31}$.

Lithuanian government started to support energy retrofits in 2005 within Multi-Apartment Building Renovation Program (2005-2010). This program stimulated investments in EE measures by combining commercial loans with up to $50 \%$ in state grants (The Residential Energy Efficiency Program in Lithuania, 2014). Starting from 2010, Housing Modernization Program through JESSICA, a financial instrument developed by EC and funded through ERDF, was the main lending mechanism for residential EE improvements. Since reorganization in 2013, a national program driven by Housing Energy Efficiency Agency seeks to renovate multi-apartment buildings built before 1993 to reduce heat (fuel) consumption by a minimum of $20 \%$.

In Lithuania, a national program was launched in 2005 to develop reference values for the building energy certification through retrofits ${ }^{32}$. Building classification consists of nine energy performance (EP) classes, ranging from A++ (NZEB) to G (energy-inefficient). It should be noted that EP classifications are not comparable between countries due to different regulations and climate conditions. For example, according to Petrasiunas (2016), the C energy class residential building in Finland is equivalent to an A class in Lithuania ${ }^{33}$. 
1 The overall aims of INSULAtE-project were to develop a protocol for assessment of the effects

2 of retrofits on indoor environmental quality (IEQ), occupant health and wellbeing, and to

3 demonstrate the effects in a sample of Finnish and Lithuanian multifamily buildings.

$4 \quad$ Additional protocol testing was conducted in Estonia, Latvia and UK. The protocol as well as

5 baseline results have been reported ${ }^{34,35}$. More detailed analyses performed thus far have

6 included a study on spatial and temporal variations of PM concentrations ${ }^{36}$; studies on building

7 related parameters including air pressure differences, air exchange rates, $\mathrm{CO}_{2}$ concentrations,

8 and hygrothermal parameters ${ }^{37-39}$; as well as occupants' satisfaction with IEQ and health ${ }^{40}$. The

9 current study continues the assessment and reports the main results related to measured energy

10 consumption and IAQ parameters. The specific aims are to study the effects of energy retrofits

11 on energy consumption as well as on the levels of chemical and biological pollutants in multifamily buildings. Recommendations related to the use of the assessment protocol are included in the discussion.

\section{Materials and methods}

\subsection{Recruitment and sampling schedule}

Buildings with planned retrofits related to EE within the project schedule (retrofits to be finished by the fall of 2014) were recruited from several regions in the middle and southern Finland and Kaunas region in Lithuania ${ }^{34}$. In addition, control buildings without planned retrofits were recruited from each country. Participation was voluntary, and the only incentive provided was a report of the measurement results at the end of the study. Survey questionnaire for buildings owners was used for the collection of building information (characteristics, condition, and retrofit activities), while checklists and basic measurements were used by field technicians to collect information about EE and structures, such as energy sources, thermal resistances of building envelope, air tightness, and heating and ventilation systems ${ }^{34,35}$. 
1 The assessment protocol included recruitment and measurements relevant to EE, indoor

2 environment, and occupants' health and satisfaction in three phases: 1) basic assessment with

3 twenty buildings from both Finland and Lithuania (about five apartments per building); 2)

4 extended assessment with a larger sample of multifamily buildings in Finland; and 3) additional

5 assessment in a set of single-family houses and/or public buildings in Finland and Lithuania,

6 as well as protocol testing in Estonia, Latvia and $\mathrm{UK}^{35}$. This study focuses on buildings enrolled

7 in phases 1 and 2 . In the following, the main groups are referred to as "case" buildings

8 (retrofitted) and "control" buildings (no retrofits). Case buildings were further divided into two

9 sub-groups based on the extent of retrofits: a) focused energy retrofits (FER) addressing single

10 system upgrades, e.g. HVAC equipment or windows (only); and b) deep energy retrofits (DER)

11 addressing multiple systems at once. The final sample included 45 buildings (240 apartments) from Finland and 20 buildings (96 apartments) from Lithuania, as shown in Table S1.

\subsection{IAQ measurements}

The measurement protocols for assessing IAQ, including standard operating procedures (SOPs) and other field study related material, have been presented in detail by Du et al. (2015) and Du et al. (2016), respectively. Figure S2 demonstrates the set up of indoor and outdoor samplers in a typical apartment. Briefly, IAQ parameters included carbon monoxide (CO) and carbon dioxide $\left(\mathrm{CO}_{2}\right)$ monitored every minute during a 24-hour period with new, factory calibrated monitors HD21AB/HD21AB17, Delta OHM, Italy. Side-by-side simultaneous tests before and after the baseline measurements were conducted, based on which replicate precision ranged from $5 \%$ to $11 \%$, and sensors were sent to manufacturer's calibration as needed (typically between pre- and post- measurement campaigns). Measurements of $\mathrm{CO}$ required valid monitoring to exceed $75 \%$ of the intended $24 \mathrm{~h}$ period (i.e. $\geq 18 \mathrm{~h}$ ). 
1 In addition, the following compounds were sampled passively with seven days exposure time:

2 nitrogen dioxide $\left(\mathrm{NO}_{2}\right)$ with Difram100 Rapid air monitor, Gradko, Ltd., England;

3 formaldehyde $\left(\mathrm{CH}_{2} \mathrm{O}\right)$ and volatile organic compounds (VOCs) represented by benzene,

4 toluene, ethyl benzene and xylenes (BTEX) with Radiello ${ }^{\text {TM }}$ Cartridge Adsorbents, Sigma-

5 Aldrich. The sample equipment was calibrated before the analyses by injecting standard

6 solutions of compounds. Radon was sampled for two months in Finnish buildings (alpha track

7 method) ${ }^{41}$ and one month in Lithuanian buildings (Standard electrets E-PERM ${ }^{\mathrm{TM}}$, Rad Elec

8 Inc.) $)^{42}$.

9 In order to measure gram-positive and gram-negative bacterial DNA as well as total fungal DNA, polyethylene coated settled dust boxes (SDBs) were placed in the living rooms of the apartments at a height of 1.0 to $2.3 \mathrm{~m}$ for the passive collection of dust settling onto these standardized surfaces over a period of two-months, similar to the approach described by Würtz et al. $^{43}$. The dust was resuspensed into buffer as described earlier ${ }^{44}$ and stored at $-20 \mathrm{C}$ until further handling. $1.8 \mathrm{~mL}$ of dust suspension were centrifuged (15 minutes at $16.000 \mathrm{x} \mathrm{g}$ ), the supernatant was reduced to $100 \mu \mathrm{L}$, which was used for DNA extraction including a beadmilling step for mechanical cell disruption and clean-up with Chemagic DNA Plant-kit (PerkinElmer chemagen Technologie GmbG, Germany) and KingFisher mL DNA extraction robot (Thermo Scientific, Finland). In order to assess and correct for the presence of inhibitors and the performance of the DNA extraction, $0.64 \mu \mathrm{g}$ of deoxyribonucleic acid sodium salt from salmon testes (Sigma Aldrich Co., USA) ${ }^{45}$ was added to the samples prior to extraction as an internal standard. Gram-positive and gram-negative bacterial DNA as well as total fungal DNA were measured via quantitative PCR (qPCR) using previously published assays ${ }^{46}$. Blank samplers and side-by-side simultaneous tests before and after the measurements were conducted for data quality assurance. 
1 Available WHO guidelines ${ }^{15,16}$, EC standards $^{47}$, and national guidelines were used for

2 interpretation of the results - where applicable - in terms of acceptability of IAQ (Table S3).

3 In Finland, the former residential and housing health guidelines ${ }^{48,49}$ were replaced in 2015 by

4 the decree on housing health ${ }^{50}$ and its implementation regulation ${ }^{51}$. Some target values can be

5 found from the indoor climate classification ${ }^{52}$. In Lithuania, national hygiene standards are 6 used as guidelines ${ }^{53,54}$.

7 The recruitment and study protocols were approved by the National Institute for Health and

8 Welfare's Ethical Research Working Group in Finland and Conduct Biomedical Research in

9 Lithuania.

\subsection{Data analysis and modelling}

Normality assumptions and correlation coefficients for continuous variables were examined.

The chi-square test was used to test differences for categorical variables. Kruskal-Wallis nonparametric test was used for differences in medians, and F and Tukey's test for means. The ratio of the between-building variance to the total variance, i.e. intra class correlations (ICC) were calculated. The larger the ICC, the lower the variability is within the buildings and consequently the higher the variability is between the buildings. In addition to descriptive statistics, the associations between retrofitting and selected IAQ indicators (incl. $\mathrm{CO}, \mathrm{NO}_{2}$, radon, $\mathrm{CH}_{2} \mathrm{O}$, BTEX, total fungi, gram-positive and gram-negative bacteria concentrations) were studied using paired analyses (including paired samples test and paired correlations) and linear mixed modelling (LMM). For the data on microbial concentrations, log-transformed values were used to normalize the distributions.

The LMM estimation was based on the Restricted Maximum Likelihood (REML) method and the Expected Maximum (EM) algorithm. The building and apartment codes were used as subject variables, and the covariance type was identity (covariance structure for a random effect 
1 with only one level). Only main effects were studied, while the factorial design with interaction

2 effects was not used. First we studied a null model, which included only the subject and

3 outcome variables without any predictors in order to examine the variance between country,

4 building and apartment levels, and to calculate the ICCs. Secondly, we included the selected

5 independent variables in the models. Retrofit status was based on case/control and pre/post

6 variables, so that the reference group was case buildings at first measurement (pre-retrofit), and

7 the other groups included case buildings at second (post-retrofit) measurement as well as

8 control buildings at first and second measurements. In addition, the fixed effects included

9 country (Finland/Lithuania) as well as outdoor temperature. We also run the models separately

10 for each country.

\section{$11 \quad 3$ Results}

\subsection{Retrofit activities}

The recruited buildings averaged $42 \pm 12$ years of age in Finland and $39 \pm 14$ in Lithuania. In

Finland, EE in the existing buildings (e.g., insulation requirements) was relatively high and most buildings had mechanical ventilation ${ }^{35}$. Thus, mainly FER activities (74\%) were done, such as changing windows, upgrading heating (e.g., new heating pipes/radiators/thermostat; geothermal heating) and/or ventilation system (e.g., new inlets/exhaust device, heat recovery system), or adding thermal insulation (three buildings had partial improvement). In Lithuania, EE in the existing buildings was relatively low and all buildings had natural ventilation. Mainly DER activities were done, including improved thermal insulation (e.g., envelop and roof), as well as replacing windows and heating systems. In some cases, renewable energy sources were added (e.g., solar collectors on the roof, data not shown). Natural ventilation systems were improved by cleaning the shafts and installing attic fans in $67 \%$ buildings, but mechanical ventilation systems were not installed (Table S1). 


\subsection{Energy consumption}

2 Energy consumption data from ten buildings in each country were available for analyses (Table

3 1). In Finland, the data were obtained mainly from building managers. It included both heating

4 and electricity consumption, and heating accounted for $91 \pm 6 \%$ and $90 \pm 9 \%$ of the total at pre-

5 and post- retrofit (data not shown). In these buildings, an average of $24.1 \pm 18.9 \%$ reduction in

6 the annual heating energy consumption was observed after the retrofits as compared to the

7 situation before retrofits. One building changed to geothermal heating system but its energy

8 consumption data were not accessible.

9 In Lithuania, monthly heating energy consumption data were collected from the municipality, based on which annual consumption was calculated. The average reduction was $49.3 \pm 20.5 \%$.

Two buildings added solar panels, which helped to reduce energy consumption by a total of $56 \%$ in both cases. Three buildings had individual space heating systems (gas boiler), and their energy consumption decreased by a total of $40 \%$.

\subsection{Indoor air quality}

Table 2 shows the concentrations of measured parameters both before and after the retrofits by group. In Finland, $\mathrm{CO}$ was detected in thirty and fifteen apartments before and after the retrofits, respectively, but the average levels were negligible (maximum concentrations were 1.38 and $0.65 \mathrm{ppm}$, respectively). In Lithuania, twenty-eight apartments had low CO concentrations before the retrofits, and four out of twenty-nine apartments had levels exceeding the national guideline (2.43 ppm) after retrofits (ranging from 2.45 to $4.19 \mathrm{ppm}$ in DER group).

A statistically significant decrease in passively sampled of $\mathrm{NO}_{2}$ was found in Finnish DER group after the retrofits (Table 2). However, there were no significant differences related to the 
1 retrofit status based on LMM (Table 3). Based on LMM, the average $\mathrm{NO}_{2}$ concentration in

2 Finnish buildings was about $8 \mu \mathrm{g} \mathrm{m}^{-3}$ lower than in Lithuanian buildings.

3 The concentrations of $\mathrm{CH}_{2} \mathrm{O}$ tended to be lower after the retrofits in Finnish buildings, whereas

4 an opposite trend was seen in Lithuanian buildings, especially in DER group (see Table 2).

5 Similar trends were seen in the control buildings between first and second measurements. The

6 type of ventilation was significantly associated with $\mathrm{CH}_{2} \mathrm{O}$ levels: the average concentration

7 was about $8 \mu \mathrm{g} \mathrm{m}^{-3}$ lower in Finnish buildings with mechanical ventilation (Table 3). A

8 negative association was seen between $\mathrm{CH}_{2} \mathrm{O}$ concentration and outdoor temperature in

9 Finland. Unlike with many other IAQ indicators, LMM estimated no country level differences 10 for $\mathrm{CH}_{2} \mathrm{O}$ (Table 3).

11 Retrofit status was associated with higher BTEX concentrations in Finnish buildings: the 12 concentration was approx. $2.5 \mu \mathrm{g} \mathrm{m}^{-3}$ higher after the retrofits (Table 2). A negative association between BTEX concentration and outdoor temperature was found in Finnish buildings (i.e. higher temperature corresponding with lower concentration), whereas in Lithuanian buildings the association was positive (i.e. higher temperature corresponding with higher concentration). The estimated mean concentration of BTEX was approximately $13 \mu \mathrm{g} \mathrm{m}^{-3}$ lower in Finnish buildings than in Lithuanian buildings (Table 3).

The mean estimated radon concentration was significantly increased (14 Bq m-3) after the retrofits in Lithuanian buildings (Table 3). In Finnish buildings, the estimated mean concentration was $10 \mathrm{~Bq} \mathrm{~m}^{-3}$ lower after the retrofits, but the decrease was not statistically significant. Radon concentrations were negatively associated with outdoor temperature. The estimated mean radon concentration in Finnish buildings was $43 \mathrm{~Bq} \mathrm{~m}^{-3}$ higher than in Lithuanian buildings. 
1 With respect to microbes, some differences in the levels before and after retrofits were observed

2 (Table 2). Based on LMM, bacteria concentrations were significantly associated with retrofit status in Finnish buildings: as compared to the initial concentration, an average of 0.6-log reduction for gram-positive bacteria and a 0.9-log reduction for gram-negative bacteria were estimated, where 0.6-log and 0.9-log reductions correspond with $\sim 4$ and 8 times smaller concentrations, respectively (Table 4). In DER group in Lithuanian buildings, the estimated mean concentration of gram-positive bacteria was significantly increased, whereas gramnegative bacteria concentrations was decreased (see opposite trend in the control group, Table 2). Outdoor temperature was negatively associated with gram-positive bacteria in Finland, whereas there was a positive trend between outdoor temperature and indoor gram-negative bacterial concentrations in both countries.

The concentration of total fungi was about 1.1-log $(\sim 12.6 \mathrm{x})$ lower in Finnish buildings than in Lithuanian buildings (Table 4). In Finland, total fungi was significantly (0.6-log) lower after the retrofits, whereas there was a statistically significant decrease in Lithuanian buildings only in DER group (Table 2). Outdoor temperature was found positively associated with the fungal concentration in Lithuania.

ICC illustrates the variance that occurs between the buildings, while the remaining proportion represents variance among the apartments within the buildings. In general, ICCs were relatively high, indicating that large proportion of variance occurs between buildings (Table 5). Lower ICC in Lithuanian data indicates that larger proportion of variance could be related to occupants and their activities.

\section{Discussion}

Space heating takes approximately $68 \%$ of the total energy use in Europe. Due to cold climate, this proportion was up to $90 \%$ in Finnish case buildings, even though the energy performance 
1 requirements have been historically higher as compared to many other EU countries ${ }^{27}$. Adding

2 thermal insulation has been proposed as the most effective way to reduce the space-heating

3 energy $^{55}$ (Pylsy and Kalema, 2008), and it was a commonly used retrofit action especially in

4 DER buildings (67\% in Finland 100\% in Lithuania). Whereas improving EE by adding

5 insulation does not reduce energy consumption in a linear fashion, noticeably high reductions

6 in the heating energy consumption was found even in Finnish case buildings. Lithuanian case

7 buildings utilized large potential of energy savings and available financial support from the

8 government by implementing deep retrofits. Consequently, a larger reduction in energy

9 consumption was observed.

The analysis related to energy consumption was limited due to the low response rate to questions on energy consumption from buildings managers in Finland: despite of multiple telephone and email contacts attempting to collect data from the building owners in Finland, we only received data from ten out of 35 retrofitted buildings. In Lithuania, data access from municipality helped in the data collection, but some buildings with individual installment of heating supply limited the collection. Nevertheless, assessing energy consumption should be considered as an essential part of the comprehensive assessment of energy retrofits, and therefore recommended to be included in the future assessments and studies on this topic.

Overall, improving EE by technical interventions alone has limited scope of influence. Similarly, energy certification is used as an instrument for reducing energy consumption and promoting renewable energy, aiming to reduce greenhouse gas emissions. However, it does not take into account IAQ, which therefore may require a separate assessment.

Regarding IAQ, this paper investigated the associations between energy retrofits and indoor chemical and biological pollutants in multifamily buildings in Finland and Lithuania. As compared to the situation before the retrofits, fungal and gram-positive (+) and negative (-) 
1 bacteria were significantly decreased in Finnish buildings after the retrofits, whereas BTEX

2 concentrations were increased. In Lithuanian buildings, and radon concentrations were significantly increased. It should be noted that the measurements were done about one year after the retrofitting; hence, long-term effects could not be estimated. As compared to other

5 studies done in this field, the follow-up period of about one year is comparable; however, it is 6 possible that some of the effects in the buildings develop gradually over time (e.g. mold growth

7 in building materials and structures due to moisture accumulation $\left.{ }^{56}\right)$ : longer follow-up studies

8 are recommended in this respect.

9 Concerning biological pollutants, the removal of old building materials, cleaning activities, or improved ventilation and/or filtration after the retrofits could contribute to the reductions of microbial content, as determined via DNA-based methodology from samples of settled dust collected. The concentrations of chemical pollutants could increase if the energy retrofit activities include indoor installations, such as new flooring or furniture; these type of changes were seen in Finnish case buildings. Such increase could be diminished by use of low emitting materials or improved ventilation ${ }^{57}$. Increase in radon concentrations, as seen in Lithuanian case buildings, could be related to decreased ventilation due to tighter building envelope together with natural ventilation system not providing compensatory air exchange, which was observed based on ventilation rate measurements ${ }^{37}$. Similar trend found in some control buildings indicated possible effects of other environmental factors as well as occupant related factors.

In Finnish buildings, relatively high ICC corresponds with low variation within buildings, which could be attributed to use of mechanical ventilation systems. Along these lines, concentrations of $\mathrm{CH}_{2} \mathrm{O}$ were negatively associated with ventilation in Finnish buildings. In addition, $\mathrm{CH}_{2} \mathrm{O}$, BTEX, radon and gram-positive bacteria were found negatively associated 
1 with outdoor temperature: ventilation rates are usually lower during cold weather as windows

2 and doors are kept closed. On the other hand, lower ICC suggested that occupants and their activities had larger influence on IAQ indicators in Lithuanian buildings with natural ventilation. The concentrations of BTEX and total fungi were positively associated with outdoor temperature, indicating outdoor influence during warmer weather due to opening of windows and doors.

Whereas information about occupants' behavior regarding their time consumption, as well as heating and ventilation (e.g. frequency opening windows and adjusting radiators valves) were collected using occupant filled diaries, the data have not been analyzed in detail so far. However, based on occupant responses on their housing satisfaction and health, significant associations were found between retrofit status and some of the measured IEQ parameters (indoor temperature OR 1.4 per $1 \mathrm{oC}$ increase, temperature factor OR 1.1 per $1 \%$ increase, and air change rate OR 5.6 per $1 / \mathrm{h}$ increase), albeit not the ones presented in this paper. Additional positive associations were found between retrofit status and occupants reporting absence of upper respiratory symptoms (OR 1.8, 95\% CI 1.1-2.9) as well as not missing work or school due to respiratory infections (OR 4.1, 95\% CI 1.2-13.8), however, these associations were independent of all measured IEQ parameters. It was concluded that there seems to be is a strong subjective component related to the observed changes in occupant satisfaction with IEQ and health as a result of energy retrofitting in buildings. Drawing definite conclusions is limited by sample size: greater variation in occupant health responses leads to smaller power in finding statistically significant associations. Therefore, further studies with larger samples are needed to verify the actual mechanisms, as well as possible long-term effects. Other study limitations include limited sampling and follow-up times. Some IAQ data, including CO, were collected only during 24 hours, while $\mathrm{BTEX}, \mathrm{CH}_{2} \mathrm{O}$ and $\mathrm{NO}_{2}$ were weekly averages. In addition, our analyses focused on the heating energy during the winter period. Regardless of our limited 
1 ability to draw definite conclusions on the potential effects of energy retrofits on IAQ, it

2 appears that with respect to improving EE of residential buildings, IAQ should be considered as a significant element that requires monitoring and evaluation, otherwise unknown and unexpected exposure may cause user dissatisfaction and adversely impact health and wellbeing. The methods and results presented in this paper can help to develop guidance and support the implementation of the EPBD in existing buildings and to complement energy audits.

\section{Recommendations}

In a wake of the new EPBD requirements coming into effect in 2020, further studies are needed, taking into account total energy consumption, and long-term financial, environmental, and societal impacts of new, existing, and retrofitted buildings. The practical experiences obtained during INSULAtE-project could be useful to other energy retrofit related projects. In the following, four recommendations are discussed to support such projects in both research and practice.

First, assessment integrating IEQ could be useful both before and after building retrofits, as well as to complement energy audits. Assessment conducted before the retrofits provides valuable information for the building designers about the needs and possibilities for improving IEQ, resulting in added value for the investment. For example, if ventilation rates are deemed inadequate before retrofits and the system cannot be adjusted to meet the recommended, then special attention could be given to identify possible ways (such as upgrading or renewing the system) to ensure adequate ventilation during and after the retrofits. Assessment conducted after the retrofits would provide assurance for that IEQ is at an appropriate level and fulfilling the standards. Governmental subsidy schemes for deep renovation could include requirements for both pre- and post-retrofit assessment as well as identified needs to address potential risks 
1 related to IEQ. Assessment conducted as a part of an energy audit would yield a more

2 comprehensive knowledge about the condition and performance of the building, including both energy and IEQ. Proposals might consider integration of voluntary indoor environment

4 certification schemes along with EPC.

Second, EE actions require the cooperation between different stakeholders, in order to achieve to the goals of energy reduction and good indoor environment for human health. Therefore, policies should take into account the co-benefits of a healthy indoor environment when assessing the energy retrofit/renovation measures, e.g. in terms of reduction of health service $\operatorname{costs}^{58}$. Both theoretical and the practical knowledge should be valued ${ }^{59}$. Increased information to homeowners on the gains of improving EE, and the availability of reliable services, would increase their participation, awareness and daily behaviors ${ }^{7}$. Occupants' motivation and their commitment to energy saving and better indoor environment objectives could be considered as a key factor for the successful results ${ }^{60}$. The more we know about how our behaviors affect energy consumption, IEQ, and health, the more likely the welfare will improve ${ }^{19}$.

Third, modern technology is promising in terms of monitoring energy consumption and IEQ (almost) real time. This can also highlight more immediate benefits. For example, occupants could react to decreased IAQ by increasing the ventilation, or adjust radiator valves for better thermal comfort, as indicated by the occupants' survey. Obtaining real time, objective information could create more factual interaction between the occupants and buildings to meet user satisfaction. Ideally, measurement and control systems will evolve in such a way that the operation of buildings can be automatically optimized to reach maximum performance in terms of sustainable, healthy, and productive indoor environments. There is a great energy saving potential related to occupant behavior, where the use of more passive, self-learning interventions could be advantageous. 
1 Finally, we recommend that international guideline or reference values should be developed

2 for the most pertinent IEQ factors. Currently many factors only have national (if any)

3 guidelines, which makes it more difficult to assess the effects of EU-level policies and

4 programmes. Given that the European building stock will go through major changes starting in

5 the next few years, it is recommended that guidance and tools for follow-up of the effects will

6 be further developed, to fully utilize the potential for improving the quality of the housing stock,

7 while also reducing its carbon footprint.

\section{Acknowledgements}

9 This work was co-financed by EU LIFE+ programme as a part of INSULAtE project (LIFE09 ENV/FI/000573) - "Improving Energy Efficiency of Housing Stock: Impacts on Indoor Environmental Quality and Public Health in Europe", and Finnish Energy Industries (THL/1759/6.00.00/2010). In addition, Lithuanian Radiation Protection Centre for provided equipment for radon measurements in Lithuania. Part of the analyses was done with a grant from Juho Vainio foundation, and writing the manuscript was partially supported by Lappeenranta University of Technology. Thanks are due to Dr. Risto Soukka from Lappeenranta University of Technology for helpful comments. We thank all building owners and occupants for participating in the study, as well as the whole INSULAtE project group and the steering board for their valuable contributions to the project.

\section{References}

1. EC. Energy-efficiency/buildings. https://ec.europa.eu/energy/en/topics/energyefficiency/buildings. 2017.

2. Laustsen J. Energy Efficiency Requirements in Building Codes , Energy Efficiency Policies for New Buildings. Buildings. 2008:1-85. 2008. http://www.iea.org/g8/2008/Building_Codes.pdf. 
$13 . \quad$ Young R, Council A. Global Approaches : A Comparison of Building Energy Codes in 15 Countries. ACEEE Summer Study Energy Effic Build. 2014:351-366.

4. Economidou M. Energy performance requirements for buildings in Europe. http://www.rehva.eu/fileadmin/hvac-dictio/03-2012/energy-performancerequirements-for-buildings-in-europe.pdf. 2012.

5. Ürge-Vorsatz D, Eyre N, Graham P, et al. Chapter 10 - Energy End-Use: Building. In: Global Energy Assessment - Toward a Sustainable Future. Cambridge University 
residential building before and after comprehensive energy retrofitting. Energy Build. 2016;123:8-16.

12. Hong SH, Gilbertson J, Oreszczyn T, Green G, Ridley I. A field study of thermal comfort in low-income dwellings in England before and after energy efficient refurbishment. Build Environ. 2009;44:1228-1236.

13. Kauko H, Alonso MJ, Stavset O, Claussen IC. Case study on residential building renovation and its impact on the energy use and thermal comfort. In: Energy Procedia. Vol 58. ; 2014:160-165.

14. Liu L, Rohdin P, Moshfegh B. Evaluating indoor environment of a retrofitted multifamily building with improved energy performance in Sweden. Energy Build. 2015;102:32-44.

15. WHO. WHO Guidelines for indoor air quality: selected pollutants. http://www.euro.who.int/_data/assets/pdf_file/0009/128169/e94535.pdf. 2010:1-22. 2010. http://whqlibdoc.who.int/hq/2006/WHO_SDE_PHE_OEH_06.02_eng.pdf?ua=1.

16. WHO. WHO Air quality guidelines for particulate matter, ozone, nitrogen dioxide and sulfur dioxide: global update 2005: summary of risk assessment. Geneva World Heal Organ. 2006:1-22. 2006.

http://whqlibdoc.who.int/hq/2006/WHO_SDE_PHE_OEH_06.02_eng.pdf?ua=1.

17. Maidment CD, Jones CR, Webb TL, Hathway EA, Gilbertson JM. The impact of household energy efficiency measures on health: A meta-analysis. Energy Policy. 2014;65:583-593.

18. Thomson H, Petticrew M, Morrison D. Health effects of housing improvement: systematic review of intervention studies. BMJ. 2001;323:187-190. 2001. http://www.bmj.com/cgi/doi/10.1136/bmj.323.7306.187.

19. Andersen S. Can the interaction between occupant behaviour and the indoor 
environment in residences be influenced? Technical University of Denmark, Department of Civil Engineering. 2016.

20. Broderick Á, Byrne M, Armstrong S, Sheahan J, Coggins AM. A pre and post evaluation of indoor air quality, ventilation, and thermal comfort in retrofitted cooperative social housing. Build Environ. 2017;122:126-133.

21. Földváry V, Bekö G, Langer S, Arrhenius K, Petráš D. Effect of energy renovation on indoor air quality in multifamily residential buildings in Slovakia. Build Environ. $2017 ; 122: 363-372$.

22. Derbez M, Berthineau B, Cochet V, et al. A 3-year follow-up of indoor air quality and comfort in two energy-efficient houses. Build Environ. 2014;82:288-299.

23. Singh MK, Attia S, Mahapatra S, Teller J. Assessment of thermal comfort in existing pre-1945 residential building stock. Energy. 2016;98:122-134.

24. Noris F, Adamkiewicz G, Delp WW, et al. Indoor environmental quality benefits of apartment energy retrofits. Build Environ. 2013;68:170-178.

25. Coombs KC, Chew GL, Schaffer C, et al. Indoor air quality in green-renovated vs. non-green low-income homes of children living in a temperate region of US (Ohio). Sci Total Environ. 2016;554-555:178-185.

26. Breysse J, Jacobs DE, Weber W, et al. Health Outcomes and Green Renovation of Affordable Housing. Public Health Rep. 2011;126:64-75. 2011. http://journals.sagepub.com/doi/10.1177/00333549111260S110.

27. Birchall S, Wallis I, Churcher D, Pezzutto S, Fedrizzi R, Causse E. D2. 1a Survey on the energy needs and architectural features of the EU building stock. EC FP7 Proj iNSPiRe, Grant Agreem. 2014.

28. Heljo J. Asuinkerros- ja rivitalojen energia-avustusten vaikutukset. (The effects of government supported energy improvements in multifamily houses, in Finnish). 
Tampere Univ Technol. 2007.

29. Ministry of Environment. Decree of Ministry of Environment on energy efficiency of new buildings. Statue of Finland. 1010/2017 (in Finnish). 2017.

30. Council of State. Decree of Council of State on energy source coefficient values used in buildings. Finlex. 788/2017. (in Finnish). 2017.

31. Ministry of the Environment. National Building Code of Finland 2012 - Section D3 on Energy Management in Buildings. http://www.gbpn.org/databases-tools/bc-detailpages/finland. 2012.

32. Stankevicius V, Karbauskaite J, Monstvilas E. The development of reference values for energy certification of buildings in Lithuania. Energy Build. 2007;39:284-288.

33. Petrasiunas R. Renovation of residential building according to Finnish and Lithuanian national building codes. 2016. 2016. http://urn.fi/URN:NBN:fi:amk-201601261672.

34. Du L, Leivo V, Martuzevicius D, Prasauskas T, Turunen M, Haverinen-Shaughnessy U. INSULAtE-Project Results - Improving Energy Efficiency of Multifamily Buildings, Indoor Environmental Quality and Occupant Health. THL. Report 17/2016.; 2016. 2016. http://urn.fi/URN:ISBN:978-952-302-772-5.

35. Du L, Prasauskas T, Leivo V, et al. Assessment of indoor environmental quality in existing multi-family buildings in North-East Europe. Environ Int. 2015;79:74-84.

36. Prasauskas T, Martuzevicius D, Krugly E, et al. Spatial and temporal variations of particulate matter concentrations in multifamily apartment buildings. Build Environ. 2014;76:10-17. June 2014. http://www.sciencedirect.com/science/article/pii/S036013231400050X.

37. Leivo V, Prasauskas T, Du L, et al. Indoor thermal environment, air exchange rates, and carbon dioxide concentrations before and after energy retro fits in Finnish and Lithuanian multi-family buildings. Sci Total Environ. 2018;621:398-406. 
1 38. Leivo V, Prasauskas T, Turunen M, et al. Comparison of air pressure difference, air change rates, and $\mathrm{CO} 2$ concentrations in apartment buildings before and after energy retrofits. Build Environ. 2017;120:85-92.

39. Leivo V, Kiviste M, Aaltonen A, Prasauskas T, Martuzevicius D, HaverinenShaughnessy U. Analysis of hygrothermal parameters in Finnish and Lithuanian multifamily buildings before and after energy retrofits. Journal of Building Physics. 2018.

40. Haverinen-Shaughnessy U, Pekkonen M, Leivo V, et al. Occupant satisfaction with indoor environmental quality and health after energy retrofits of multi-family buildings: Results from INSULAtE-project. Int J Hyg Environ Health. 2018;221:921928.

41. Reisbacka H. Radon measurement method with passive alpha track detector at STUK, Finland. in: Proceedings of Third European IRPA Congress, 14-18 June 2010, Helsinki, Finland.

42. Pilkyte L, Butkus D, Morkunas G. Assessment of external dose indoors in Lithuania. Radiat Prot Dosimetry. 2006;121:140-147.

43. Würtz H, Sigsgaard T, Valbjørn O, Doekes G, Meyer HW. The dustfall collector--a simple passive tool for long-term collection of airborne dust: a project under the Danish Mould in Buildings program (DAMIB). Indoor Air. 2005;15 Suppl 9:33-40.

44. Huttunen K, Tirkkonen J, Täubel M, et al. Inflammatory potential in relation to the microbial content of settled dust samples collected from moisture-damaged and reference schools: results of HITEA study. Indoor Air. 2016;26:380-390.

45. Haugland RA, Siefring SC, Wymer LJ, Brenner KP, Dufour AP. Comparison of Enterococcus measurements in freshwater at two recreational beaches by quantitative polymerase chain reaction and membrane filter culture analysis. Water Res. 2005;39:559-568. 
46. Kärkkäinen PM, Valkonen M, Hyvärinen A, Nevalainen A, Rintala H. Determination of bacterial load in house dust using qPCR, chemical markers and culture. J Environ Monit. 2010;12:759-68. 2010.

http://www.ncbi.nlm.nih.gov/pubmed/20445866\%5Cnhttp://pubs.rsc.org/en/content/art iclehtml/2010/em/b917937b.

47. EC. Air Quality Standards. http://ec.europa.eu/environment/air/quality/standards.htm. 2013.

48. MSAH. Indoor Air Guide (Sisäilmaohje, in Finnish). Handbooks Minist Soc Aff Heal. 1997.

49. MSAH. "Finnish Residential Health Guide" (Asuntojen ja muiden oleskelutilojenfysikaaliset, kemialliset ja mikrobiologiset tekijät) (In Finnish). 2003.

50. MSAH. Housing Health Regulations (Asumisterveysasetus 525/2015. Sosiaali- ja terveysministeriön asetus asunnon ja muun oleskelutilan terveydellisistä olosuhteista sekä ulkopuolisten asiantuntijoiden pätevyysvaatimuksista)(In Finnish). 2015.

51. Valvira. Implementation of the Housing Health Regulations (Asumisterveysasetuksen soveltamisohje) (In Finnish). 2016.

52. Rakennustieto. Classification on Indoor Environment 2008. Target values, design guidance and product requirements. LVI 05-10440en. 2010.

53. LRS. Lietuvos higienos norma HN 35:2007, Didžiausia leidžiama cheminių medžiagu (teršalų) koncentracija gyvenamosios aplinkos ore (in Lithuanian). https://eseimas.lrs.lt/portal/legalAct/lt/TAD/TAIS297779. 2007.

54. LRS. Lietuvos higienos norma HN 42:2009, Gyvenamųų ir visuomeninių pastatų patalpų mikroklimatas (in Lithuanian). https://eseimas.lrs.lt/portal/legalAct/lt/TAD/TAIS362676. 2009.

55. Pylsy P, Kalema T. Concepts for low-energy single-family houses. Tampereen Tek 

yliopisto Konstr laitos Tutkimusraportti. 2008.

2 56. Viitanen H, Vinha J, Salminen K, et al. Moisture and bio-deterioration risk of building materials and structures. J Build Phys. 2010;33:201-224.

4 57. Offermann FB, Marcham C. A Review of Studies of Ventilation and Indoor Air Quality in New Homes and Impacts of Environmental Factors on Formaldehyde Emission Rates From Composite Wood Products. 2016.

58. Ferreira M, Almeida M. Benefits from energy related building renovation beyond costs, energy and emissions. In: Energy Procedia. Vol 78. ; 2015:2397-2402.

9

59. Palm J, Reindl K. Understanding energy efficiency in Swedish residential building renovation: A practice theory approach. Energy Res Soc Sci. 2016;11:247-255.

60. McGill G, Oyedele LO, Keeffe G, Keig P. Indoor air quality and the suitability of mechanical ventilation with heat recovery (MVHR) systems in energy efficient social housing projects: perceptions of UK building professionals. Int J Sustain Build Technol Urban Dev. 2014;5:240-249. 


\section{Tables and figures}

2 Table 1. Annual heating energy consumptions in Finland and Lithuania.

\begin{tabular}{|c|c|c|c|c|c|c|c|c|c|c|}
\hline \multirow{3}{*}{$\begin{array}{l}\text { Country } \\
\text { Retrofit levels } \\
\text { Unit, } \mathrm{kWh} / \mathrm{m}^{2}\end{array}$} & \multicolumn{5}{|c|}{ Finland } & \multicolumn{5}{|c|}{ Lithuania } \\
\hline & \multicolumn{2}{|l|}{ FER } & \multicolumn{2}{|l|}{ DER } & \multirow{2}{*}{$\begin{array}{l}\text { Total } \\
\Delta, \%{ }^{\mathrm{b}}\end{array}$} & \multicolumn{2}{|l|}{ FER } & \multicolumn{2}{|l|}{ DER } & \multirow{2}{*}{$\begin{array}{l}\text { Total } \\
\Delta, \%^{\mathrm{b}}\end{array}$} \\
\hline & Pre & Post & Pre & Post & & Pre & Post & Pre & Post & \\
\hline $\mathrm{N}$ & 8 & & 2 & & 10 & 1 & & 9 & & 10 \\
\hline Average & 143.5 & 116.6 & 169.0 & 100.7 & -24.1 & 55.6 & 53.8 & 118.2 & 53.4 & -49.3 \\
\hline SD & 35.6 & 42.9 & 33.5 & 23.1 & 18.9 & - & - & 25.9 & 13.9 & 20.5 \\
\hline Min & 101 & 44.0 & 145.3 & 84.4 & -4.5 & - & - & 87.7 & 39.6 & -3.3 \\
\hline Max & 190.5 & 175.9 & 192.7 & 117.0 & -56.4 & - & - & 172.7 & 75.0 & -66.5 \\
\hline
\end{tabular}

${ }^{a}$ FER: focused energy retrofits, DER: deep energy retrofits; ${ }^{b}$ Percentage of energy at post- retrofit compared to pre- condition. 
2 Finland and Lithuania by group. Bolded values are significant at $\alpha=0.05$ between pre- and post- retrofit data (paired test).

\begin{tabular}{|c|c|c|c|c|c|c|c|c|c|c|c|c|c|}
\hline \multirow{3}{*}{$\begin{array}{l}\text { Para- } \\
\text { meter }\end{array}$} & \multirow{3}{*}{ Group $^{a}$} & \multicolumn{6}{|c|}{ Finland } & \multicolumn{6}{|c|}{ Lithuania } \\
\hline & & \multicolumn{3}{|c|}{ Pre $/ 1^{\text {st }}$} & \multicolumn{3}{|c|}{ Post $/ 2^{\text {nd }}$} & \multicolumn{3}{|c|}{ Pre $/ 1^{\text {st }}$} & \multicolumn{3}{|c|}{ Post $/ 2^{\text {nd }}$} \\
\hline & & $\mathrm{N}$ & Ave.(SD) & $\mathrm{P}, \%^{\mathrm{b}}$ & $\mathrm{N}$ & Ave.(SD) & $\mathrm{P}, \%^{\mathrm{b}}$ & $\mathrm{N}$ & Ave.(SD) & $\mathrm{P}, \%^{\mathrm{b}}$ & $\mathrm{N}$ & Ave.(SD) & $\mathrm{P}, \%^{\mathrm{b}}$ \\
\hline \multirow{3}{*}{$\begin{array}{l}\mathrm{CO} \\
\mathrm{ppm}\end{array}$} & Control & 18 & $0.00(0.00)$ & 0 & 12 & $0.01(0.04)$ & 0 & 22 & $0.12(0.36)$ & 0 & 8 & $0.17(0.22)$ & 0 \\
\hline & FER & 129 & $0.03(0.14)$ & 0 & 88 & $0.03(0.11)$ & 0 & 7 & $0.05(0.12)$ & 0 & 5 & $0.25(0.43)$ & 0 \\
\hline & DER & 25 & $0.06(0.27)$ & 0 & 16 & $0.03(0.10)$ & 0 & 59 & $0.19(0.51)$ & 0 & 52 & $0.38(0.90)$ & 8 \\
\hline \multirow{3}{*}{$\begin{array}{l}\mathrm{NO}_{2} \\
\mu \mathrm{g} \mathrm{m}^{-3}\end{array}$} & Control & 16 & 3.94 (1.63) & - & 13 & $5.70(2.85)$ & - & 22 & $14,99(7,10)$ & - & 8 & $13,07(5,31)$ & - \\
\hline & FER & 121 & $7.30(4.13)$ & - & 86 & $7.30(5.03)$ & - & 9 & $12.57(5.97)$ & - & 5 & $12.64(4.71)$ & - \\
\hline & DER & 25 & $7.02(2.45)$ & - & 18 & $5.37(2.08)$ & - & 62 & $13.84(8.34)$ & - & 47 & $13.92(8.45)$ & - \\
\hline \multirow{3}{*}{$\begin{array}{l}\mathrm{CH}_{2} \mathrm{O} \\
\mu \mathrm{g} \mathrm{m}^{-3}\end{array}$} & Control & 16 & $16.36(5.12)$ & - & 13 & $13.38(3.49)$ & - & 24 & $16.22(6.09)$ & - & 8 & $32.99(10.90)$ & - \\
\hline & FER & 116 & $19.81(7.97)$ & - & 86 & $19.22(8.28)$ & - & 9 & $28.28(12.33)$ & - & 5 & $17.27(5.76)$ & - \\
\hline & DER & 24 & $17.79(6.25)$ & - & 17 & $15.34(5.35)$ & - & 62 & $25.11(10.41)$ & - & 52 & 32.37 (13.19) & - \\
\hline \multirow{3}{*}{$\begin{array}{l}\text { BTEX } \\
\mu \mathrm{g} \mathrm{m}^{-3}\end{array}$} & Control & 16 & $7.69(6.25)$ & - & 13 & $8.85(4.48)$ & - & 24 & $11.44(12.45)$ & - & 8 & $16.01(23.43)$ & - \\
\hline & FER & 98 & $10.89(13.63)$ & - & 86 & $11.19(7.17)$ & - & 9 & $21.80(11.97)$ & - & 5 & $22.07(5.61)$ & - \\
\hline & DER & 25 & $5.76(2.66)$ & - & 16 & $7.80(1.89)$ & - & 62 & $27.29(28.82)$ & - & 50 & $24.76(13.40)$ & - \\
\hline \multirow{3}{*}{$\begin{array}{l}\text { Radon } \\
\mathrm{Bq} \mathrm{m}^{-3}\end{array}$} & Control & 13 & $48.46(23.40)$ & 0 & 12 & $50.83(29.68)$ & 0 & 12 & $20.59(16.97)$ & 0 & 4 & $16.88(5.87)$ & 0 \\
\hline & FER & 104 & $74.71(59.45)$ & 6 & 74 & 73.65 (59.19) & 0 & 5 & $20.97(13.69)$ & 0 & 4 & $45.13(18.26)$ & 0 \\
\hline & DER & 21 & $59.52(57.83)$ & 5 & 14 & $40.00(26.02)$ & 0 & 28 & $34.34(26.22)$ & 0 & 27 & $43.69(28.18)$ & 0 \\
\hline \multirow{3}{*}{$\begin{array}{l}\text { Bacteria, } \\
\text { gram+ } \\
\text { cells } / \mathrm{m}^{2} / \mathrm{d}\end{array}$} & Control & 11 & $19200(26800)$ & - & 10 & $25300(48700)$ & - & 22 & $62500(60400)$ & - & 5 & $164100(174900)$ & - \\
\hline & FER & 58 & $22600(39900)$ & - & 41 & $8600(22300)$ & - & 9 & $84000(153200)$ & - & 4 & $294000(344000)$ & - \\
\hline & DER & 23 & $15500(20300)$ & - & 15 & $86800(320400)$ & - & 60 & $70800(106700)$ & - & 47 & $98400(215400)$ & - \\
\hline
\end{tabular}




\begin{tabular}{|c|c|c|c|c|c|c|c|c|c|c|c|c|c|}
\hline \multirow{3}{*}{$\begin{array}{l}\text { Bacteria, } \\
\text { gram- } \\
\text { cells } / \mathrm{m}^{2} / \mathrm{d}\end{array}$} & Control & 11 & $7400(9000)$ & - & 10 & $8700(17400)$ & - & 22 & $82800(85500)$ & - & 5 & $87300(87500)$ & - \\
\hline & FER & 58 & $24700(76300)$ & - & 41 & $6600(14100)$ & - & 9 & $66000(102200)$ & - & 4 & $193500(230800)$ & - \\
\hline & DER & 23 & $36300(53300)$ & - & 15 & $3000(4900)$ & - & 60 & $99300(256700)$ & - & 47 & $85000(167700)$ & - \\
\hline \multirow{3}{*}{$\begin{array}{l}\text { Fungi } \\
\text { cells } / \mathrm{m}^{2} / \mathrm{d}\end{array}$} & Control & 11 & $400(430)$ & - & 10 & $430(670)$ & - & 22 & $7300(10400)$ & - & 5 & $30500(40100)$ & - \\
\hline & FER & 58 & $1600(3900)$ & - & 41 & $370(660)$ & - & 9 & $7200(12800)$ & - & 4 & $13700(14500)$ & - \\
\hline & DER & 23 & $1400(2000)$ & - & 15 & $180(230)$ & - & 60 & $27300(137900)$ & - & 47 & $6700(13800)$ & - \\
\hline
\end{tabular}

${ }^{\text {a }}$ FER: focused energy retrofits, DER: deep energy retrofits, pre: before retrofits, post: after retrofits (corresponding to $1^{\text {st }}$ and $2^{\text {nd }}$ measurement for "control" group); ${ }^{\mathrm{b}}$ Percentage of apartments with average concentrations that failed the guideline values (considering WHO as a priority guideline, EU secondary and national levels third). 
Table 3. Linear mixed model (LMM) for $\mathrm{NO}_{2}$, formaldehyde $\left(\mathrm{CH}_{2} \mathrm{O}\right)$, benzene, toluene, ethyl benzene and xylenes (BTEX) and radon concentration.

\begin{tabular}{|c|c|c|c|c|c|c|c|c|c|c|c|c|}
\hline \multirow{2}{*}{ Parameter } & \multicolumn{4}{|l|}{ All } & \multicolumn{4}{|l|}{ Finland } & \multicolumn{4}{|l|}{ Lithuania } \\
\hline & \multirow[t]{2}{*}{ Estimate } & \multicolumn{2}{|l|}{$95 \% \mathrm{CI}$} & \multirow[t]{2}{*}{ Sig. } & \multirow[t]{2}{*}{ Estimate } & \multicolumn{2}{|l|}{$95 \% \mathrm{CI}$} & \multirow[t]{2}{*}{ Sig. } & \multirow[t]{2}{*}{ Estimate } & \multicolumn{2}{|c|}{$95 \% \mathrm{CI}$} & \multirow[t]{2}{*}{ Sig. } \\
\hline $\mathrm{NO}_{2}$ & & Lower & Upper & & & Lower & Upper & & & Lower & Upper & \\
\hline Intercept & 14.12 & 12.83 & 15.41 & $* * *$ & 6.81 & 5.37 & 8.25 & $* * *$ & 13.96 & 11.90 & 16.03 & $* * *$ \\
\hline Country & & & & & 0 & . & . & & 0 & . & . & \\
\hline Finland & -7.65 & -9.98 & -5.31 & $* * *$ & & & & & & & & \\
\hline Lithuania $^{\mathrm{a}}$ & 0 & . & . & & & & & & & & & \\
\hline \multicolumn{13}{|c|}{ Retrofit status } \\
\hline Control; $2^{\text {nd }}$ & -1.94 & -4.43 & 0.56 & & -1.47 & -3.68 & 0.75 & & -5.44 & -11.83 & 0.96 & $\dagger$ \\
\hline Case; post & -0.40 & -1.23 & 0.42 & & -0.38 & -0.91 & 0.15 & & -0.52 & -2.78 & 1.73 & \\
\hline Control; $1^{\text {st }}$ & -.47 & -2.56 & 1.63 & & -3.23 & -5.42 & -1.03 & $* *$ & 1.28 & -2.81 & 5.37 & \\
\hline Case; pre ${ }^{\mathrm{a}}$ & 0 & . & . & & 0 & . & . & & 0 & . & . & \\
\hline \multicolumn{13}{|c|}{ Type of ventilation } \\
\hline Mechanical & .34 & -1.85 & 2.53 & & .35 & -1.24 & 1.95 & & 0 & . & . & \\
\hline Natural $^{\mathrm{a}}$ & 0 & . & . & & 0 & . & . & & 0.24 & -0.07 & 0.56 & \\
\hline Tout & 0.09 & -0.04 & 0.21 & & 0.00 & -0.10 & 0.10 & & 13.96 & 11.90 & 16.03 & \\
\hline \multicolumn{13}{|l|}{$\mathrm{CH}_{2} \mathrm{O}$} \\
\hline Intercept & 26.84 & 24.46 & 29.22 & $* * *$ & 28.23 & 24.54 & 31.91 & $* * *$ & 25.06 & 22.18 & 27.94 & $* * *$ \\
\hline Country & & & & & 0 & . & . & & 0 & . & . & \\
\hline Finland & -0.56 & -4.80 & 3.68 & & & & & & & & & \\
\hline Lithuania $^{\mathrm{a}}$ & 0 & . & . & & & & & & & & & \\
\hline \multicolumn{13}{|c|}{ Retrofit status } \\
\hline Control; $2^{\text {nd }}$ & -0.56 & -5.74 & 4.62 & & -5.86 & -11.99 & 0.27 & $\dagger$ & 4.79 & -4.81 & 14.39 & \\
\hline Case; post & 1.33 & -0.83 & 3.49 & & -1.33 & -3.69 & 1.03 & & 5.63 & 1.83 & 9.43 & $* *$ \\
\hline Control; $1^{\text {st }}$ & -7.04 & -11.03 & -3.06 & $* *$ & -4.84 & -10.66 & 0.98 & & -8.87 & -14.39 & -3.35 & $* *$ \\
\hline Case; pre ${ }^{\mathrm{a}}$ & 0 & . & . & & 0 & . & . & & 0 & . & . & \\
\hline Type of vent & tilation & & & & & & & & 0 & . & . & \\
\hline Mechanical & -7.82 & -11.84 & -3.80 & $* * *$ & -8.14 & -12.11 & -4.18 & $* * *$ & & & & \\
\hline Natural $^{\mathrm{a}}$ & 0 & . & . & & 0 & . & . & & & & & \\
\hline Tout & -0.16 & -0.41 & 0.10 & & -0.44 & -0.75 & -0.13 & $* *$ & 0.32 & -0.15 & 0.80 & \\
\hline \multicolumn{13}{|l|}{ BTEX } \\
\hline Intercept & 24.04 & 20.69 & 27.39 & $* * *$ & 11.60 & 7.56 & 15.63 & $* * *$ & 27.40 & 22.28 & 32.53 & $* * *$ \\
\hline Country & & & & & 0 & . & . & & 0 & . & . & \\
\hline Finland & -13.42 & -19.48 & -7.36 & $* * *$ & & & & & & & & \\
\hline Lithuania $^{\mathrm{a}}$ & 0 & . & . & & & & & & & & & \\
\hline \multicolumn{13}{|c|}{ Retrofit status } \\
\hline Control; $2^{\text {nd }}$ & -5.19 & -12.09 & 1.70 & & -0.71 & -6.91 & 5.50 & & -21.97 & -39.11 & -4.82 & $*$ \\
\hline Case; post & 0.28 & -2.40 & 2.97 & & 2.50 & 0.74 & 4.26 & $* *$ & -5.06 & -11.95 & 1.84 & \\
\hline
\end{tabular}


Control; $1^{\text {st }}-8.71$

Case; pre ${ }^{\mathrm{a}} \quad 0$

Type of ventilation

Mechanical 0.30

Natural $^{\mathrm{a}} \quad 0$

Tout

$\begin{array}{lll}0.018 & -0.33 & 0.37\end{array}$ $\begin{array}{lll}-3.22 & -9.31 \quad 2.86\end{array}$

0

$\begin{array}{lll}-1.61 & -6.11 \quad 2.88\end{array}$

0

$\begin{array}{lll}-0.36 & -0.67 & -0.06\end{array} *$
$-16.96 \quad-26.76-7.16 \quad * *$

0

0

$\begin{array}{lll}1.15 & 0.29 & 2.01\end{array} * *$

\section{Radon}

Intercep

39.28

$22.3756 .19 * * *$

$\begin{array}{lll}87.07 & 64.31 \quad 109.83\end{array}$

0

*** 29.46

0

Country

$43.46 \quad 17.64 \quad 69.28 \quad * *$

Lithuania $^{\mathrm{a}} 0$

Retrofit status

Control; $2^{\text {nd }}-12.01$

Case; post $\quad-4.27 \quad-13.64 \quad 5.11$

$\begin{array}{lll}-18.83 & -55.17 & 17.51\end{array}$

$\begin{array}{lll}-11.44 & -40.10 & 17.23\end{array}$

Control; $1^{\text {st }}-24.36$

$\begin{array}{lll}-9.66 & -21.00 & 1.68\end{array}$

$\dagger \quad 13.87 \quad 2.28 \quad 25.46 *$

Case; pre ${ }^{\mathrm{a}} \quad 0$

$-48.44-0.28 *$

$\begin{array}{lll}-34.18 & -69.59 & 1.23\end{array}$

0

$\dagger \quad-8.82 \quad-23.84 \quad 6.19$

Type of ventilation

Mechanical -12.21

$-34.28 \quad 9.87$

$\begin{array}{lll}-12.63 & -37.67 & 12.42\end{array}$

Natural $^{\mathrm{a}} \quad 0$

0

Tout

$-1.59$

$-2.98 \quad-0.21$

$\begin{array}{lll}-2.41 & -4.26 & -0.57\end{array}$

$-1.45 \quad 1.34$

${ }^{a}$ This parameter is set to zero because it is redundant. ${ }^{*} \mathrm{p}<0.05 * * \mathrm{p}<0.01 * * * \mathrm{p}<0.001 \dagger \mathrm{p}<0.1$ 
Table 4. Linear mixed model (LMM) for log transformed gram-positive (+) and gram-negative (-) bacteria and fungi concentrations.

\begin{tabular}{|c|c|c|c|c|c|c|c|c|c|c|c|c|}
\hline \multirow{2}{*}{ Parameter } & \multicolumn{4}{|l|}{ All } & \multicolumn{4}{|l|}{ Finland } & \multicolumn{4}{|l|}{ Lithuania } \\
\hline & \multirow{2}{*}{$\begin{array}{l}\text { Estimate } \\
\text { ive }\end{array}$} & \multicolumn{2}{|c|}{$95 \% \mathrm{CI}$} & \multirow[t]{2}{*}{ Sig. } & \multirow[t]{2}{*}{ Estimate } & \multicolumn{2}{|c|}{$95 \% \mathrm{CI}$} & \multirow[t]{2}{*}{ Sig. } & \multirow[t]{2}{*}{ Estimate } & \multicolumn{2}{|l|}{$95 \% \mathrm{CI}$} & \multirow[t]{2}{*}{ Sig. } \\
\hline Gram-positi & & Lower & Upper & & & Lower & Upper & & & Lower & Upper & \\
\hline Intercept & 4.33 & 4.12 & 4.54 & $* * *$ & 3.99 & 3.55 & 4.42 & $* * *$ & 4.11 & 3.84 & 4.38 & $* * *$ \\
\hline Country & & & & $* * *$ & 0 & . & . & & 0 & . & . & \\
\hline Finland & -.73 & -1.20 & -.26 & & & & & & & & & \\
\hline Lithuania $^{\mathrm{a}}$ & 0 & . & . & & & & & & & & & \\
\hline \multicolumn{13}{|c|}{ Retrofit status } \\
\hline $\begin{array}{l}\text { Control; } \\
2^{\text {nd }}\end{array}$ & .17 & -.37 & .72 & & -.17 & -.76 & .41 & & .65 & -.40 & 1.70 & \\
\hline Case; post & -.20 & -.46 & .05 & & -.61 & -.91 & -.32 & $* * *$ & .30 & -.10 & .69 & \\
\hline Control; $1^{\text {st }}$ & .23 & -.14 & .61 & & -.01 & -.58 & .55 & & .39 & -.13 & .92 & \\
\hline Case; pre ${ }^{\mathrm{a}}$ & 0 & . & . & & 0 & . & . & & 0 & . & . & \\
\hline Type of vent & ilation & & & & & & & & 0 & . & . & \\
\hline Mechanical & .07 & -.40 & .53 & & -.10 & -.55 & .34 & & & & & \\
\hline Natural $^{\mathrm{a}}$ & 0 & . & . & & 0 & . & . & & & & & \\
\hline Tout & -.01 & -.04 & .02 & & -.04 & -.08 & -.01 & $*$ & .01 & -.04 & .06 & \\
\hline \multicolumn{13}{|c|}{ Gram-negative } \\
\hline Intercept & 4.50 & 4.30 & 4.70 & $* * *$ & 3.79 & 3.39 & 4.20 & $* * *$ & 4.21 & 3.96 & 4.47 & $* * *$ \\
\hline Country & & & & & 0 & . & . & & 0 & • & . & \\
\hline Finland & -.97 & -1.42 & -.53 & $* * *$ & & & & & & & & \\
\hline Lithuania $^{\mathrm{a}}$ & 0 & . & . & & & & & & & & & \\
\hline \multicolumn{13}{|c|}{ Retrofit status } \\
\hline $\begin{array}{l}\text { Control; } \\
2^{\text {nd }}\end{array}$ & -.34 & -.86 & .18 & & -.69 & -1.23 & -.15 & $*$ & .32 & -.68 & 1.32 & \\
\hline Case; post & -.46 & -.70 & -.22 & $* * *$ & -.94 & -1.22 & -.67 & $* * *$ & .18 & -.19 & .55 & \\
\hline Control; $1^{\text {st }}$ & .06 & -.30 & .42 & & -.27 & -.79 & .26 & & .38 & -.12 & .89 & \\
\hline Case; pre ${ }^{\mathrm{a}}$ & 0 & . & . & & 0 & . & . & & 0 & . & . & \\
\hline Type of vent & ilation & & & & & & & & 0 & . & . & \\
\hline Mechanical & .15 & -.29 & .59 & & .10 & -.31 & .52 & & & & & \\
\hline Natural $^{\mathrm{a}}$ & 0 & . & . & & 0 & . & . & & & & & \\
\hline Tout & .03 & .01 & .06 & $*$ & .02 & -.01 & .05 & & .03 & -.02 & .07 & \\
\hline \multicolumn{13}{|l|}{ Fungi } \\
\hline Intercept & 3.51 & 3.35 & 3.68 & $* * *$ & 2.69 & 2.37 & 3.02 & $* * *$ & 3.36 & 3.14 & 3.58 & $* * *$ \\
\hline Country & & & & & 0 & . & . & & 0 & . & . & \\
\hline Finland & -1.07 & -1.45 & -.69 & $* * *$ & & & & & & & & \\
\hline Lithuania $^{a}$ & 0 & . & . & & & & & & & & & \\
\hline
\end{tabular}


$\begin{array}{llll}\text { Control; } & -.03 & -.45 & .39\end{array}$

$\begin{array}{llllllll} & -.40 & -.84 & .04 & \dagger & .53 & -.21 & 1.28 \\ * * * & -.62 & -.84 & -.39 & * * * & -.06 & -.30 & .19 \\ & -.36 & -.79 & .07 & & .12 & -.30 & .55 \\ 0 & . & . & & 0 & . & . \\ & & & & & 0 & . & .\end{array}$

Case; post $\quad-.36 \quad-.54 \quad-.18$

Control; $1^{\text {st }}-. .05 \quad-.34 \quad .24$

Case; pre ${ }^{\mathrm{a}} \quad 0$

Type of ventilation

$\begin{array}{lllllll}\text { Mechanical } & .07 & -.31 & .45 & -.02 & -.35 & .32 \\ \text { Natural }^{\mathrm{a}} & 0 & . & . & 0 & . & .\end{array}$

$\begin{array}{lllllll}\text { Tout } & .02 & -.01 & .04 & -.00 & -.03 & .02\end{array}$

${ }^{\mathrm{a}}$ This parameter is set to zero because it is redundant. ${ }^{*} \mathrm{p}<0.05 * * \mathrm{p}<0.01 * * * \mathrm{p}<0.001 \dagger \mathrm{p}<0.1$ 
Table 5. Intra class correlations (ICC) for IAQ indicator variables

\begin{tabular}{llll}
\hline \multirow{2}{*}{ IAQ indicator variable } & \multicolumn{3}{c}{ ICC } \\
\cline { 2 - 4 } & All & Finland & Lithuania \\
\hline $\mathrm{NO}_{2}$ & 0.74 & 0.80 & 0.56 \\
$\mathrm{CH}_{2} \mathrm{O}$ & 0.43 & 0.51 & 0.22 \\
$\mathrm{BTEX}$ & 0.57 & 0.74 & 0.40 \\
Radon & 0.70 & 0.71 & 0.27 \\
Gram-positive bacteria $(\log )$ & 0.22 & a & 0.24 \\
Gram-negative bacteria $(\log )$ & 0.24 & a & 0.27 \\
Total fungi (log) & 0.49 & a & 0.52 \\
\hline a This covariance parameter is redundant. & &
\end{tabular}




\section{SUPPLEMENTAL MATERIAL FOR}

\section{Effects of Energy Retrofits on Indoor Air Quality in Finnish and Lithuanian Multifamily Buildings}

Table $\mathrm{S} 1$. Retrofit activities ( $\mathrm{N}$ is the number of buildings).

\begin{tabular}{|c|c|c|c|c|c|c|c|c|}
\hline \multirow{2}{*}{$\begin{array}{l}\text { Country } \\
\text { Retrofit levels }\end{array}$} & \multicolumn{4}{|c|}{ Finland $(\mathrm{N}=45)$} & \multicolumn{4}{|c|}{ Lithuania $(\mathrm{N}=20)$} \\
\hline & Control & FER & DER & Per, $\%^{\mathrm{b}}$ & Control & FER & DER & Per, $\%^{b}$ \\
\hline \multicolumn{9}{|l|}{ Baseline } \\
\hline No. of buildings (apartments) ${ }^{\mathrm{c}}$ & $8(35)$ & $28(163)$ & $9(42)$ & 100 & $5(24)$ & $2(9)$ & $13(63)$ & 100 \\
\hline Building area, $\mathrm{m}^{2}$ & 5678 & 3249 & 3506 & 47 & 3921 & 2885 & 3439 & 80 \\
\hline Number of floors, $n$ & 6 & 5 & 5 & 70 & 10 & 4 & 5 & 100 \\
\hline Number of apartments, $n$ & 32 & 48 & 28 & 79 & 56 & 53 & 41 & 100 \\
\hline \multicolumn{9}{|l|}{ Ventilation system, $\%{ }^{d}$ : } \\
\hline Mechanical & 100 & 83 & 75 & 76 & 0 & 0 & 0 & 100 \\
\hline Natural & 0 & 17 & 25 & 76 & 100 & 100 & 100 & 100 \\
\hline \multicolumn{9}{|l|}{ Retrofit activities, \%: } \\
\hline Thermal insulation of envelope & - & 11 & 67 & - & - & 0 & 100 & - \\
\hline
\end{tabular}

${ }^{\mathrm{a}}$ FER: focused energy retrofits, DER: deep energy retrofits; ${ }^{b}$ Percentage of buildings with information collected; ${ }^{\mathrm{c}}$ One building had no information collected but measurement was conducted; ${ }^{\mathrm{d}}$ In Lithuania, some apartments installed exhaust in kitchen and/or bathroom; ${ }^{\mathrm{e}}$ In Lithuania means 'Cleaned ventilation shafts and installed new fans in the attics'. 
Figure S2. Location of indoor and outdoor samplers in a typical apartment
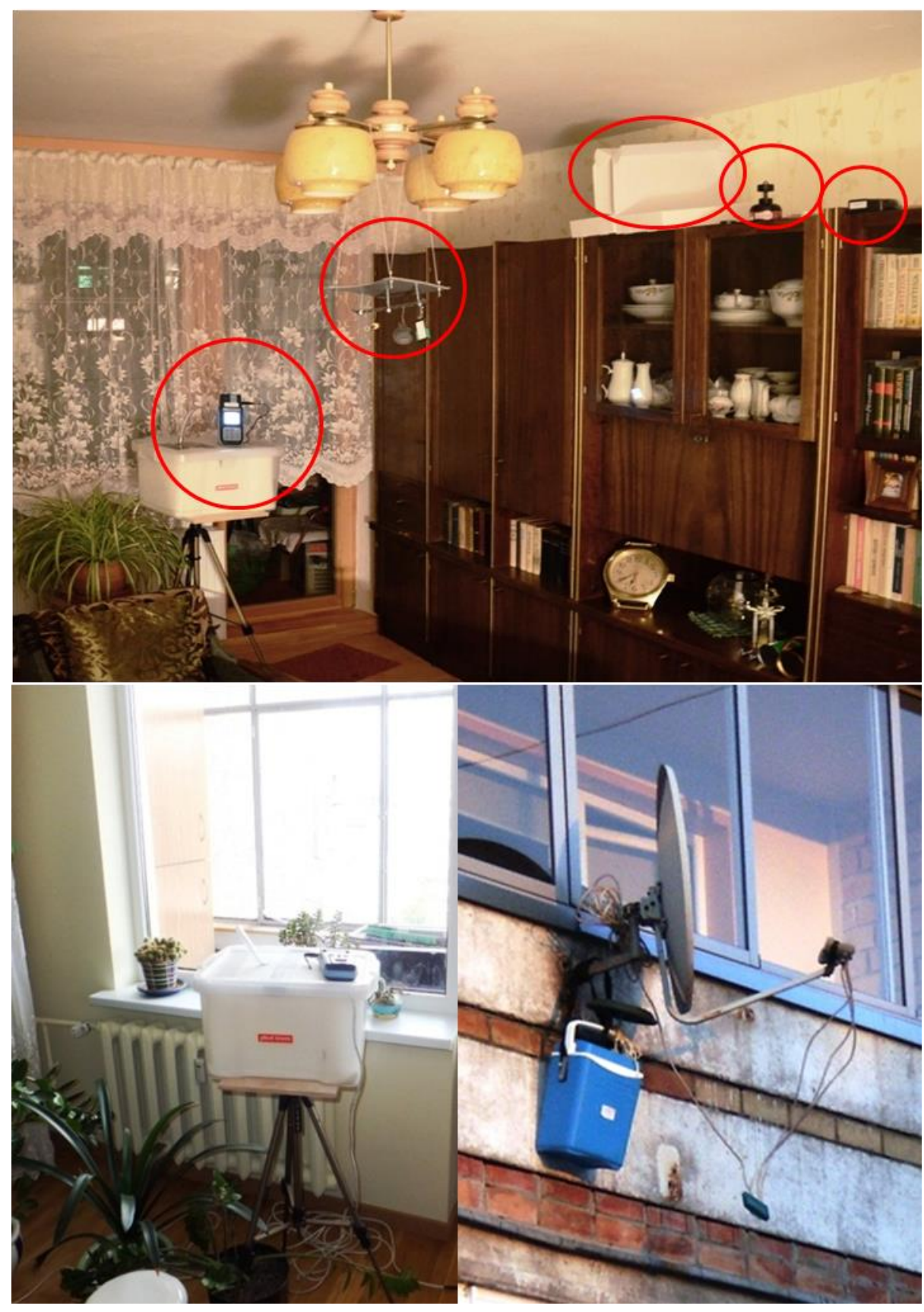
Table S3. Some IAQ guideline values from WHO, EU and national levels.

\begin{tabular}{|c|c|c|c|c|c|}
\hline \multirow{2}{*}{ Parameter } & \multirow{2}{*}{ Unit } & \multirow{2}{*}{ WHO } & \multirow{2}{*}{ EU } & \multicolumn{2}{|c|}{ National guideline } \\
\hline & & & & Finland & Lithuania \\
\hline $\mathrm{CO}^{1}$ & $\mathrm{ppm}$ & $8.6(8 \mathrm{~h}) ; 25(1 \mathrm{~h})$ & $10(8 \mathrm{~h})$ & 7 & $2.43(24 \mathrm{hr})$ \\
\hline $\mathrm{PM}_{2.5}$ & $\mu \mathrm{g} / \mathrm{m}^{3}$ & $25(24 \mathrm{hr})$ & $25(\mathrm{yr})$ & - & 40 (24hr) \\
\hline $\mathrm{PM}_{10}$ & $\mu \mathrm{g} / \mathrm{m}^{3}$ & $50(24 \mathrm{hr})$ & $50(24 \mathrm{hr}) ; 40(\mathrm{yr})$ & - & $50(24 \mathrm{hr})$ \\
\hline $\mathrm{NO}_{2}$ & $\mu \mathrm{g} / \mathrm{m}^{3}$ & $40(\mathrm{yr}) ; 200(\mathrm{hr})$ & $200(\mathrm{hr}) ; 40(\mathrm{yr})$ & - & $40(24 \mathrm{hr})$ \\
\hline Formaldehyde & $\mu \mathrm{g} / \mathrm{m}^{3}$ & $100(30 \mathrm{~min})$ & - & $50(\mathrm{yr})$ & $\begin{array}{l}100(30 \mathrm{~min}) \\
10(24 \mathrm{hr})\end{array}$ \\
\hline Radon & $\mathrm{Bq} / \mathrm{m}^{3}$ & $100(\mathrm{yr})$ & - & $100 / 200 / 400^{2}$ & 400 \\
\hline TVOCs & $\mu \mathrm{g} / \mathrm{m}^{3}$ & - & - & 400 & $100^{3}$ \\
\hline
\end{tabular}

${ }^{1}$ Values refer to maximum daily 8-hour mean.

${ }^{2}$ Guideline values in Finland: $100 \mathrm{~Bq} \mathrm{~m}^{-3}$ (new buildings); $200 \mathrm{~Bq} \mathrm{~m}^{-3}$ (built after 1992).

${ }^{3}$ Lithuanian guideline is for aliphatic hydrocarbons of C1-C10 structure $\left(100 \mathrm{mg} / \mathrm{m}^{3}\right)$. 